\title{
Correction to: The influence of corruption and governance in the delivery of frontline health care services in the public sector: a scoping review of current and future prospects in low and middle-income countries of south and south-east Asia
}

\author{
Nahitun Naher ${ }^{1 *}$, Roksana Hoque ${ }^{1}$, Muhammad Shaikh Hassan, Dina Balabanova², Alayne M. Adams ${ }^{3}$ and \\ Syed Masud Ahmed ${ }^{1}$
}

\section{Correction to: BMC Public Health (2020) 20:880 https://doi.org/10.1186/s12889-020-08975-0}

It was highlighted that the original article [1] contained an error in the Acknowledgment and the Funding section. This Correction article shows the correct Acknowledgment section and Funding section.

\section{Acknowledgments}

Authors acknowledge support from SamiunNazrinBente Kamal Tune, Senior Research Associate, BRAC James P. Grant BRAC School of Public Health, BRAC University for helping with organizing and formatting the references. This study is part of a large multicountry partnership, the SOAS Anti-Corruption Evidence (ACE) research consortium. For more information on SOAS-ACE visit: www.ace.soas.ac.uk

\section{Funding}

This publication is an output of the SOAS AntiCorruption Evidence (ACE) research consortium funded by UK aid from the UK Government [Contract PO
7073]. The views presented are those of the author(s) and do not necessarily reflect the UK government's official policies or the views of SOAS-ACE or other partner organisations.

\section{Author details}

${ }^{1}$ BRAC James P. Grant BRAC School of Public Health, BRAC University, 5th Floor (Level-6), icddrb Building, 68 ShahidTajuddin Ahmed Sarani, Mohakhali, Dhaka 1212, Bangladesh. 'Department of Global Health and Development, London School of Hygiene and Tropical Medicine (LSHTM), Room TP 308, 15-17 Tavistock Place, London WC1H 9SH, UK. ${ }^{3}$ Department of Family Medicine, Faculty of Medicine, McGill University, 5858 Cote des Neiges, Room 332, Montréal, Québec H3S 1Z1, Canada.

Published online: 09 July 2020

\section{Reference}

1. Naher $\mathrm{N}$, et al. The influence of corruption and governance in the delivery of frontline health care services in the public sector: a scoping review of current and future prospects in low and middle-income countries of south and south-east Asia. BMC Public Health. 2020;20:880. https://doi.org/10. 1186/s12889-020-08975-0.
The original article can be found online at https://doi.org/10.1186/s12889020-08975-0.

* Correspondence: nahitun.naher@bracu.ac.bd

1 BRAC James P. Grant BRAC School of Public Health, BRAC University, 5th

Floor (Level-6), icddrb Building, 68 ShahidTajuddin Ahmed Sarani, Mohakhali, Dhaka 1212, Bangladesh

Full list of author information is available at the end of the article

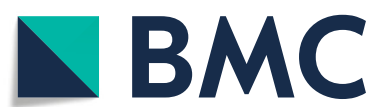

c) The Author(s). 2020 Open Access This article is licensed under a Creative Commons Attribution 4.0 International License, which permits use, sharing, adaptation, distribution and reproduction in any medium or format, as long as you give appropriate credit to the original author(s) and the source, provide a link to the Creative Commons licence, and indicate if changes were made. The images or other third party material in this article are included in the article's Creative Commons licence, unless indicated otherwise in a credit line to the material. If material is not included in the article's Creative Commons licence and your intended use is not permitted by statutory regulation or exceeds the permitted use, you will need to obtain permission directly from the copyright holder. To view a copy of this licence, visit http://creativecommons.org/licenses/by/4.0/. The Creative Commons Public Domain Dedication waiver (http://creativecommons.org/publicdomain/zero/1.0/) applies to the data made available in this article, unless otherwise stated in a credit line to the data. 